\title{
Corruption and Financial Management: Evidence from Korean Local Governments*
}

\author{
Eunji Kim** and Sangheon Kim***
}

\begin{abstract}
Academic researchers have paid lots of attention to corruption and there have been therefore numerous studies on the subject. Withal the rich literature on corruption, it is hard to find studies trying to investigate the effects of corruption on financial management of local governments. This article empirically tests the argument that corruption undermines local government's incentives for good financial management and increases the debt level with a unique Korean index of corruption, Integrity Scores published by Anti-Corruption \& Civil Right Commission of Korea. According to OLS analyses, integrity has a negative and significant effect on the debt ratio. This supports the idea that the more local governments are corrupted, the less incentive they have to maintain a sound financial condition.
\end{abstract}

Keywords: corruption, local government, financial management

\section{INTRODUCTION}

Corruption is a ubiquitous phenomenon around the world across ages and societies. It might not be a burdensome task to prove that it has coexisted with the history of human beings. There are various types of corruption in developed countries, developing countries and transition economies. It has attracted people's attention from practitioners as well as from academia. We can even find courses and trainings at schools. Some schools offer MA degrees in this field such as National University of Malaysia,

\footnotetext{
* We are very grateful to the seminar participants at the BK21 conference held in New York on 20th of July for their very constructive comments.

** Ph.D., Fellow at Public Finance Research Center. Graduate School of Public Administration, Seoul National University. E-mail: transcendent@snu.ac.kr.

*** Professor, Graduate School of Public Administration. Seoul National University. E-mail: sanghkim@snu.ac.kr.
}

Manuscript received August 10, 2015; out for review August 14, 2015; review completed August 21, 2015; accepted August 24, 2015.

The Korean Journal of Policy Studies, Vol. 30, No. 2 (2015), pp. 177-192.

(C) 2015 by the GSPA, Seoul National University 
International Academy of Anti-corruption, and University of Sussex.

Academic researchers have also paid lots of attention to corruption and there have been therefore numerous studies on the subject. Following the study by Shleifer and Vishny (1993), the majority of studies has attempted to analyze the association of corruption with economic effects. However, it is not easy to find any studies investigating the relationship between corruption and financial management at the local government level.

It is not hard to suppose that corruption might affect local government's incentives for financial management. If a local government is not corrupt, it will probably be responsive to constituents' demand for public goods and services. Therefore, it has a strong incentive to keep the financial condition sound. On the contrary, financial conditions will deteriorate in corrupted local governments since they do not care for the constituents' preference. In addition, corrupted local governments might be vulnerable to interest group's lobbies. This implies also that corruption leads to bad financial managements.

Considering fiscal distress accumulating at the local level, it is very important to figure out what factors are influential on worsening local government's financial conditions. In this article, we argue that one significant factor be corruption in the public sector. It undermines local government's incentives for good financial management and increases the debt level. To test the validity of this argument, we set up an empirical model and estimate it with data from Korean local governments.

The rest of the article is composed as follows. The section reviews the literature concerning corruption, especially focusing on the relationship between corruption and financial managements. In section III, the politics of local governments and its association with corruption are discussed at the local level. A testable hypothesis is also suggested. Empirical model and results are shown in section IV. The final section concludes.

\section{LITERATURE}

Studies on corruption began long time ago and we can witness numerous and diverse research. A complete literature review on this will take a serious volume of a book. One topic that has drawn researchers' attention most heavily is the relationship between corruption and economic growth.

The relationship between corruption and growth has been studied for a long time, and the results are very diverse. Generally, researches view corruption as an obstructive 
factor to economic growth and these are supported by the results of the empirical literatures. However, there are also conflicting results that it appears differently depending on the context of a country, the level of culture and economic condition.

Traditionally, the possibility that corruption may be able to have positive impact on growth has been raised as well. In other words, corruption may increase economic efficiency in certain conditions. Huntington (1968) argues corruption increases growth by helping agents avoid bureaucratic delays in a way which is so called 'grease in the wheel.' It means the politicians who resort to corrupt practices are able to tame the public servants who have become powerful in those societies (W. A. Wijewardena, 2015). The weakening of the bureaucracy helps these societies to develop their political parties. Corruption becomes an easy way to moderate conflicts between agents and thereby it can help societies to simulate economic development.

In contrast, the view which corruption is related to economic variables such as efficiency, income, and investment is dominant and a variety of studies have demonstrated this. Mauro (1995) provides empirical evidence on the effect of corruption on economic growth by using data set consisting of subjective indices of bureaucratic honesty and efficiency. He concluded that the negative association between corruption and investment, as well as growth, is significant statistically. Maher (1986) also reaches a similar conclusion that corruption may raise efficiency by deductive micro-economics methodology. A number of studies view corruption causes the fall in investment and conclude corruption interrupts growth or it is related growth directly as a negative correlation (Knack and Keefer, 1995; Tanzi and Davoodi, 2000; Shang Jin Wei, 2000; Rcock and Bonnett, 2004).

When considering several factors, the results of analysis of the relationship between corruption and growth are inconsistent. Generally, corruption has been identified as a factor that hinders growth, but when it comes to the sample consists of developing countries, the negative effect of corruption is reduced significantly (Meon and Sekkat, 2005; Aidt et al., 2008). According to such researches, it can be concluded that corruption is a ubiquitous phenomenon around the world but its effects can be different depending on across ages, societies and economic conditions (Bardhan, 1997; Svensson, 2005).

More recent studies on the relationship between corruption and economic growth go in several different directions. Some started to view the phenomenon of corruption not in isolation, but as part of the broader issue of governance and public management (Schaeffer, 2002; Tanzi, 1998). They consider corruption neither beneficial ('grease for the machine'), nor inevitable ('it's always worked this way'), nor respectable ('everybody does it') (ADB, 2001). 
Others try to separate the effects of corruption on growth according to appropriate variables. Assiotis and Sylwester (2014) assumed that the effect might differ across democratic and nondemocratic regimes. It concludes that corruption harms economic growth more in authoritarian regimes than in democratic countries. The authors provides reasons for this that corruption generates more uncertainty, is more pernicious, or decreases substitutability with other forms of rent seeking in autocracies. Ugur (2014) uses a meta-analysis to estimate the effects of corruption on economic growth, noticing the mixed results. It shows that the effect is more adverse if the growth variable is long-run and only low-income countries are used. It is also noticeable that the effect is less adverse when the International Country Risk Guide corruption perceptions index is used.

There have been studies on the relationship between corruption and financial performance even if they are not fully rich considering the literature on the effects of corruption on economic growth. Tanzi is one of the most prominent figures in this subject. He argues that "corruption and poor governance may affect economic performance through their impact on tax revenue, public spending, and fiscal deficit." In addition, he asserts that "a study to investigate empirically the impact of corruption on tax structure shows that high-level corruption reduces tax revenue: a one-point increase in the corruption index reduces tax revenue collected by 2.7 percent of GDP." He also argues that corruption increases tax evasion. But Goerke (2008)'s assertion is in the opposite direction: policy measure affecting gains/losses from corruption have a nonsystematic impact on tax evasion behavior.

Some studies deal with the association of corruption and sovereign bond rating. Depken and Lafountain (2006), for instance, investigates the effect of corruption on state bond ratings in the United States and finds that more corrupt states tend to have lower bond ratings. In the meanwhile, others have focused on the expenditure side of government finance and its relationship with corruption. Moschovis (2010) argues that corruption affects the decision makings on government spending allocation, increasing expenditures for general public services, defense, order and safety, economic affairs and culture. Corruption is, however, negatively associated with social expenditure. He also asserts that corruption influences execution phase of the budget, pushing government spending above the budgetary targets and therefore leading to fiscal slippages and poor fiscal performance.

Dzhumashev (2014) investigates the two-way relationship between corruption and public spending, trying to explain the empirical regularity that an increase in public spending gives rise to a reduction of economic growth in low-income countries. He shows that government spending increase corruption and rent seeking distorting the 
Table 1. Financial Conditions of Local Governments in Korea

\begin{tabular}{|c|c|c|c|c|c|c|c|}
\hline & & 2009 & 2010 & 2011 & 2012 & 2013 & 2014 \\
\hline \multirow{3}{*}{ Debt } & Total amount & 255,531 & 289,933 & 281,618 & 271,252 & 285,886 & 277,071 \\
\hline & $\begin{array}{l}\text { High-level local } \\
\text { government }\end{array}$ & 177,100 & 204,443 & 197,432 & 192,113 & 216,654 & 218,114 \\
\hline & Low-level government & 78,431 & 85,490 & 84,186 & 79,139 & 69,232 & 61,903 \\
\hline \multirow{6}{*}{$\begin{array}{l}\text { Financial } \\
\text { Independence } \\
\text { Rate }\end{array}$} & Mean & 53.6 & 52.2 & 51.9 & 52.3 & 51.1 & 44.8 \\
\hline & $\begin{array}{l}\text { Special city \& } \\
\text { Metropolitan city }\end{array}$ & 72.7 & 68.3 & 68.6 & 69.1 & 66.8 & 61.5 \\
\hline & Province & 33.3 & 31.6 & 33 & 34.8 & 34.1 & 29 \\
\hline & City & 40.7 & 40 & 38 & 37.1 & 36.8 & 31.7 \\
\hline & County & 17.8 & 18 & 17.1 & 16.4 & 16.1 & 11.4 \\
\hline & Autonomous district & 37.3 & 35.4 & 36.6 & 36 & 33.9 & 27.2 \\
\hline \multirow{6}{*}{$\begin{array}{l}\text { Financial } \\
\text { Autonomy } \\
\text { Rate }\end{array}$} & Mean & 78.9 & 75.7 & 76.7 & 77.2 & 76.6 & 69.4 \\
\hline & $\begin{array}{l}\text { Special / Metropolitan/ } \\
\text { Special autonomous city }\end{array}$ & 81.2 & 76.3 & 78.5 & 79.2 & 77.4 & 71.4 \\
\hline & Province & 49.5 & 46 & 47.5 & 49.2 & 48.8 & 42.7 \\
\hline & City & 71.5 & 69.1 & 68.7 & 68.4 & 67.7 & 61.3 \\
\hline & County & 64.6 & 62.2 & 62.7 & 62.9 & 63.9 & 58.4 \\
\hline & Autonomous district & 61.8 & 57.9 & 56.2 & 55.6 & 52.2 & 44.2 \\
\hline
\end{tabular}

Note: 1) Financial independence rate and financial autonomy rate: The standard of mean is net amount, while others are total amount.

2) The figures of financial autonomy rate in 2014 are estimates.

Source: 1) www.index.go.kr

2) lofin.mospa.go.kr

structure and size of public spending. Social losses become larger with a higher level of rent dissipation and a concomitant rise in corruption and government inefficiency, resulting in a decline of economic growth. Arvate et al. (2010) tries to test the causality between government size and corruption. It is concluded that the size of government spending Granger causes corruption in OECD and developing countries and good governance is recommended to prevent corruption.

Withal the rich literature on corruption, it is hard to find studies trying to investigate the effects of corruption on financial management of local governments. It is quite surprising considering the bad financial conditions at the local level. Financial conditions 
across Korean local governments are seriously bad, especially at the low-level as shown in the following table. A more serious problem is that they tend to deteriorate over time. Things need to be done to alleviate the problem. This article aims to provide one reason for the bad financial situation in local governments, corruption.

\section{CORRUPTION AND FINANCIAL MANAGEMENT AT THE LOCAL LEVEL}

Before investigating the relationship between corruption and financial management at the local level, we need to understand the local government system in the Korean peninsula. Korea had maintained a highly centralized government system since a long time ago. In early 1990s it adopted a new system, autonomy of local governments. In 1991, local parliaments were formed and in 1995 the heads of the executive branch of local governments were elected by constituents.

There are three tiers in the Korean government system: one central government, special/metropolitan cities/provinces, and cities/counties/districts. As shown in the following table, there are 8 special/metropolitan cities, 9 provinces (including on special autonomous one, Jeju), and each of these higher levels of governments has its own cities/counties/districts.

There are good reasons for decentralization, widely accepted in public finance and political science. The most prominent justification is by Tiebout (1956) that decentralization enhances efficiency with 'vote by feet' compared to a centralized system. Oates (1972) also has a similar line of argument. It is also argued that decentralized local governments are more responsive to the needs of constituents than a centralized one. Political scientists assert that decentralization is beneficial to the society since it promotes 'grass-root democracy.'

Another justification for accepting autonomy of local governments is the mechanism in which constituents become more interested in local government's activities and therefore the possibility of corruption in the public sector decreases. Since the local governments in a decentralized system are in an arm's reach of the public, politicians and public officials cannot be bribed easily.

There is, however, an opposite view on the relationship between decentralization and corruption. Since interest groups are more active at the local level and they can keep a closer relation with politicians and public officials, decentralization might tend to increase corruption. Put in other words, governments are more easily captured in a decentralized system at the local level than in a centralized one. 
Table 2. Local Governments in Korea

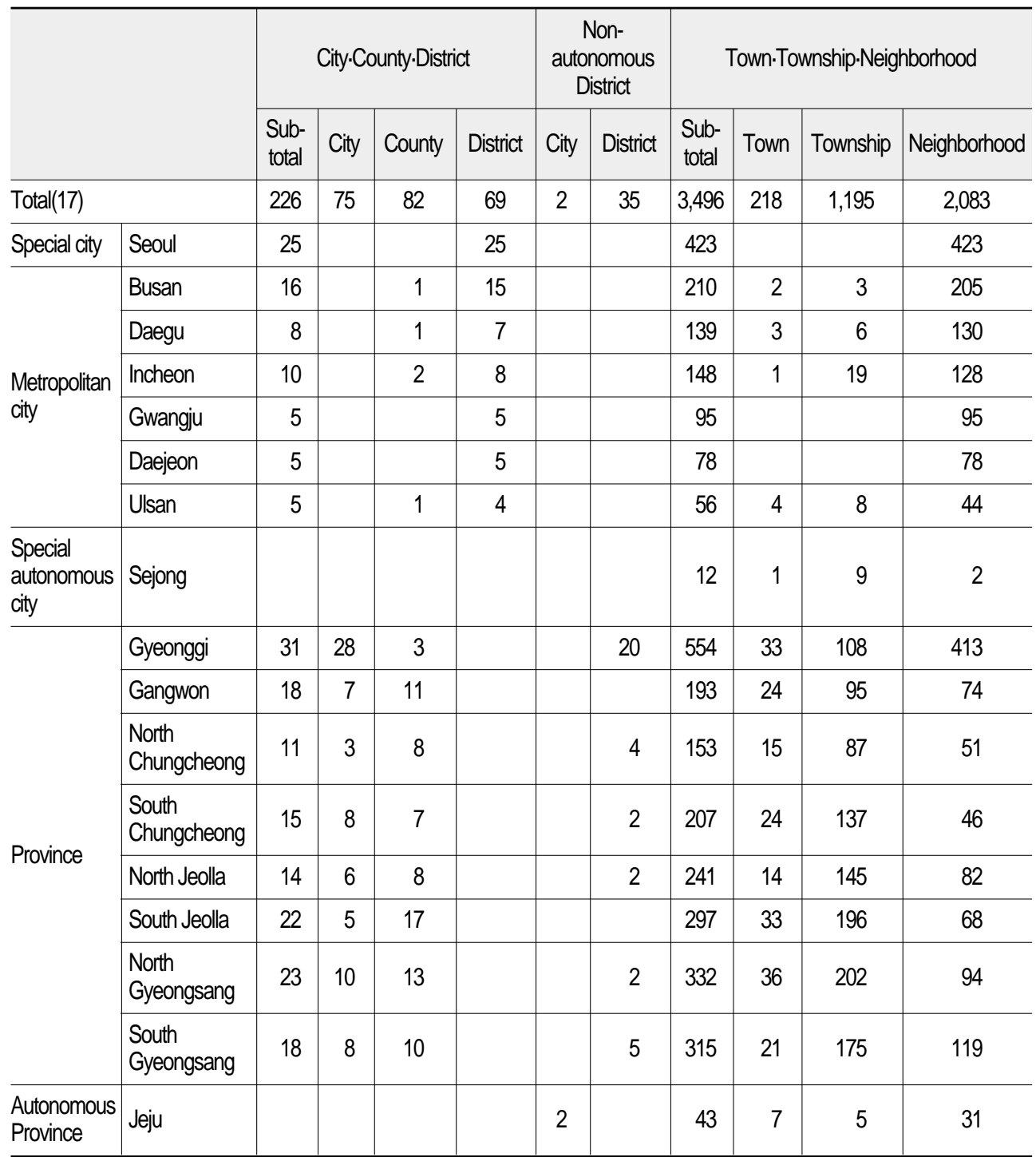

Source: Ministry of Government Administration and Home Affairs (2015), The Current Status of Population and Administrative District in Local Governments.

The literature is mixed regarding this issue, leaving a room for reinvestigation. Some argues the positive association between them (Shleifer and Vishny 1993; Bardhan 2002; Fisman and Gatti, 2002; Lecuna, 2012). Others find a negative relationship (Huther and Shah 1998; de Mello and Barenstein 2001; Arikan, 2004). There are also several studies 
Figure 1. Distribution of Corruption Level across Korean Local Governments

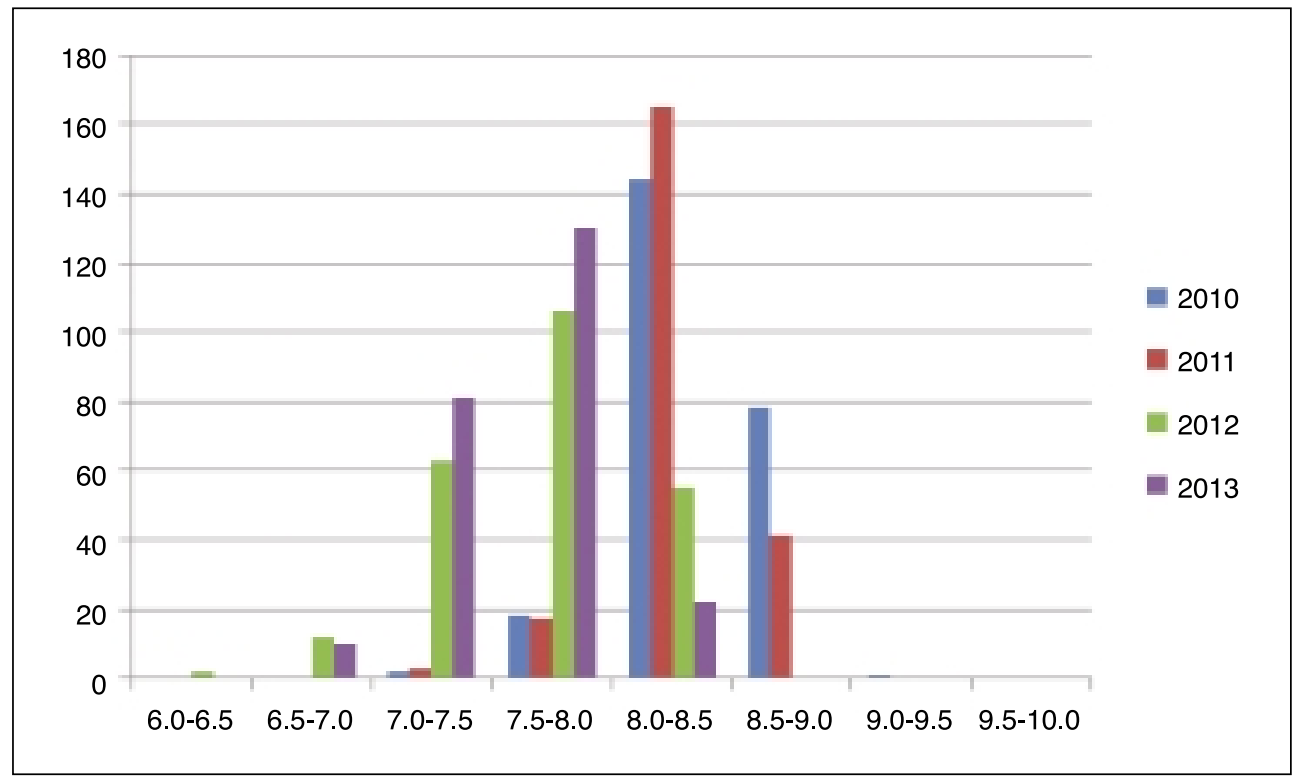

Note: $x$-axis - scale of integrity (smaller number means more corruption) $y$-axis - number of local governments.

emphasizing that the overall results are inconclusive and suggest reasonable conditions determining the effect of decentralization on corruption (Bjedov, Tjasa; Madies, Thierry; Schnyder, Simon, 2010; Goel and Nelson, 2011; Alexeev and Habodaszova, 2012).

Whatever the relationship might be between decentralization and corruption, it is not the main focus of this study. However, we could see that decentralization and corruption are highly correlated, giving much variation in the level of corruption among local governments. Since the effects of corruption on financial management of decentralized local governments are our interest, the variation is helpful for us to investigate the association between corruption and financial management.

To examine the relationship between corruption and financial managements, the behaviors of main players concerning financial management should be explained at first. Local politicians and heads of the executive branch of local governments strive to be re-elected. For this reason, they should be responsive to interest groups. At the same time, they should also be responsive to the needs of general constituents. Therefore, there are two counter forces influencing their behavior.

Corruption implies that politicians and public officials utilize their power and discretion to their benefits rather than to meet the needs of constituents. Therefore, it might be reasonable to guess that they do care more about the interest groups than about the 
public. Put in other words, politicians and public officials in corrupted regions have little incentives to maintain a sound fiscal condition. To be more specific about the debt of local governments, they might be inclined to spend than to save, making the balance sheet red and increasing debts.

However, the story goes quite differently if general constituents are very alert to the financial conditions of their government. This phenomenon might be witnessed where constituents are well-educated and care about government's activities. Since they are aware of financial conditions of local governments and take them into account when they vote, politicians and public officials cannot help listening to their needs and maintaining a sound fiscal condition.

As seen above, it is totally possible to assert based on theoretical backgrounds that the effects of corruption on financial management of local governments go in either direction, negative and positive. The investigation of those effects falls in the area of empirical analysis. However, it is hard to find any study examining the effects empirically. This article tries to fill the gap in the literature.

\section{EMPIRICAL EVIDENCE}

\section{Model Specification}

The relationship that this article mainly deals with is between corruption and financial management of local governments. This implies that the independent variable should be corruption and the dependent financial management. We also need a set of appropriate control variables influencing the dependent variable.

There are lots of definitions on corruption but they are not different to a significant extent. According to Tanzi (1998), corruption means "the abuse of public power for private benefit. Corruption can be defined in different ways. However, the most common definition is that it is the abuse of public power to promote private benefits. Thus, a public employee who abuses his/her public position to derive benefits for oneself or friends, relatives or political associates is engaging in an act of corruption. Not all cases of corruption involve the payment of bribes." OECD defines corruption in a similar way. "Corruption is the misuse of public or private office for personal gain." (Managing Public Expenditure: A Reference Book For Transition Countries, OECD, p. 447).

Measurement of corruption is more difficult than defining it. Tanzi notices it and emphasizes that corruption perception indices are widely used withal their shortcomings. 
"While no direct measurement of corruption exists, following a trend that is becoming more and more common in economics and in other fields such as political science and sociology, in recent years, data have become available that attempt to measure not corruption per se but people's perceptions of the prevalence of corruption." "In this approach, presumably informed observers are asked to rank countries, often on a score of 1 (most corrupt) to 10 (least corrupt). It is not always clear whether the samples are random and large enough to provide statistically acceptable results. It is also not clear to which extent the data are fully comparable across countries and over time. However, there are now at least six institutions, including Transparency International and the World Bank, that have been generating data on the perception of corruption. In spite of their shortcomings, the data are being used with increasing frequency by economists in their cross-country statistical studies." (Tanzi, 1998)

This paper uses "the degree of integrity" presented by Korean Civil Right Commission (KCRC) annually as the independent variable. The factors that determine the overall integrity are divided into additional point factors and penalty point factors. Additional point factors consist of external integrity, internal integrity and customer's policy reviews. External integrity evaluates gratuities, entertainment, whether there are pursuits of private interests and whether job performance is transparent. Internal integrity evaluates whether corruption is rampant within the organization. Policy reviews are performed by professionals, business stakeholders, and residents about concerned agencies. Penalty point factors depend on the occurrence of corruption incident and the act of compromising reliability. Internal or external integrity and policy reviews are evaluated through surveys. In contrast, corruption cases and the act of compromising reliability are evaluated by scoring the actual disciplinary cases.

As discussed above, the dependent variable is financial management of local governments. There can be various measurements for financial management. One of the most widely used proxies is local government's debt level. If a local government manages well its financial situation, its debt level might be controlled in a good manner and vice versa. The ratio of debt to total budget is used so that comparison across local governments may be feasible.

The following figure shows a simple relationship between corruption and debt in Korean local governments. As can be seen easily, there seem to be negatively associated.

The fiscal conditions and demographics affect the financial condition of local governments. The higher fiscal autonomy score, the range of the budget which local government can expend autonomously is wider. In a different aspect, financial power index shows the degree of revenue side of local governments. It shows how much fiscal revenue compared to fiscal demand cover the criteria which local governments provide a standard administrative service. That is, the higher the index value means 
Figure 2. Corruption and Debt Ratio in Korean Local Governments

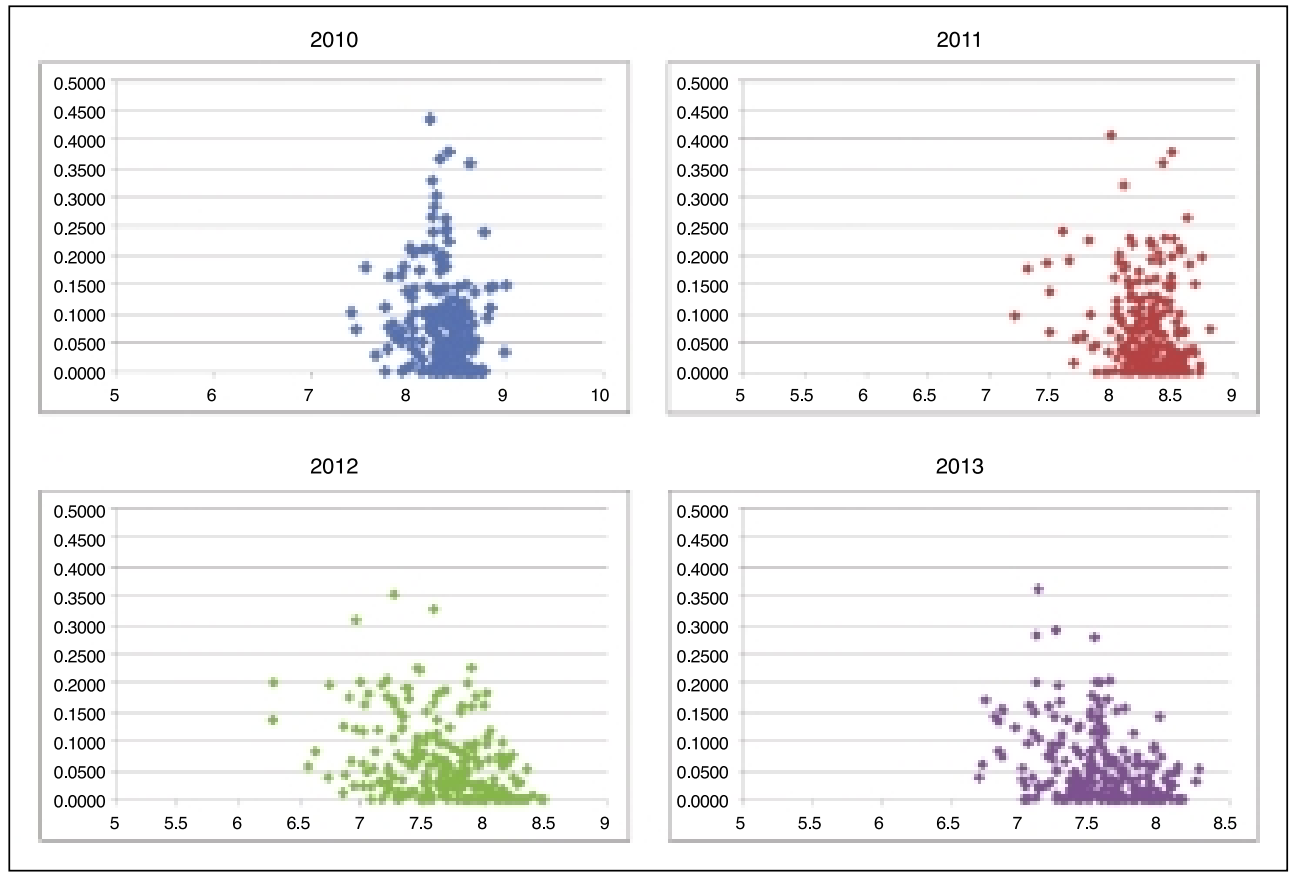

Note: $x$-axis - integrity index

$y$-axis - debt ratio to budget

revenue capability to corresponding to the demand of administrative service of local governments is superb. Meanwhile, consolidated budget balance means the figure that net financial income balanced net financial expenses in the current year.

Based on the discussions up to now, an empirical regression model can be expressed as follows. DEBT is the ratio of debt to total budget in local governments and IN is the integrity index. $\mathrm{X}$ is a vector of control variables. Coefficients to be estimated are denoted as $\alpha, \beta$, and $\gamma$. The last term $\varepsilon$ is an error term.

$$
\mathrm{DEBT}=\alpha+\beta \mathrm{IN}+\mathrm{X} \gamma+\varepsilon
$$

\section{Data and Results}

Data for the estimation of the empirical model are collected mainly from the government statistics documents. The next table summarizes variables and their data sources. 
Table 3. Variables and Data Sources

\begin{tabular}{l|l|l|c}
\hline & \multicolumn{1}{|c|}{ Variable Name } & \multicolumn{1}{c}{ Data Source } & Data Span \\
\hline $\begin{array}{l}\text { Dependent } \\
\text { Variable }\end{array}$ & Debt to budget ratio & $\begin{array}{l}\text { Statistics by the Ministry of } \\
\text { Government Administration and } \\
\text { Home Affairs }\end{array}$ & 2010-2013 \\
$\begin{array}{l}\text { Independent } \\
\text { Variable }\end{array}$ & Integrity score & $\begin{array}{l}\text { Anti-Corruption \& Civil Right } \\
\text { Commission of Korea }\end{array}$ & $2010-2013$ \\
\hline $\begin{array}{l}\text { Control } \\
\text { Variables }\end{array}$ & $\begin{array}{l}\text { Fiscal autonomy score } \\
\text { Financial power index } \\
\text { Consolidated fiscal balance } \\
\text { Population } \\
\text { Year dummies }\end{array}$ & $\begin{array}{l}\text { Statistics by the Ministry of } \\
\text { Government Administration and } \\
\text { Home Affairs }\end{array}$ & $2010-2013$ \\
\hline
\end{tabular}

The following table shows the descriptive statistics of the variables.

Table 4. Descriptive Statistics

\begin{tabular}{l|c|c|r|r}
\hline \multicolumn{1}{c|}{ Variable name } & \multicolumn{1}{c|}{ Mean } & Standard deviation & Minimum & Maximum \\
\hline Debt to budget ratio & 0.0700 & 0.0738 & 0 & 0.4324 \\
\hline Integrity score & 7.9621 & 0.5003 & 6.28 & 9.01 \\
\hline Fiscal autonomy score & 62.227 & 11.4241 & 0.6239 & 91.05 \\
\hline fiscal power index & 0.38710 & 0.3008 & 0.032 & 1.681 \\
\hline consolidated fiscal balance & -0.0772 & 0.0462 & -0.2873 & 0.0405 \\
\hline population & 582081.8 & 1466140 & 10325 & $1.21 \mathrm{e}+07$ \\
\hline
\end{tabular}

OLS estimation results of regression equation (1) are shown in the next table. Several models have been estimated for a robustness check of the independent variable. Model 1 includes the independent variable only, not controlling for other possible factors which could have impacts on the dependent variable. Model 2, 3 and 4 have different control variables to check the robustness of the coefficient of the independent variable.

The table shows that integrity has a negative and significant effect on the debt ratio in all models. Regardless of the model, it is statistically significant to reject the null hypothesis at the .01 level that the coefficient is zero at the population. This supports the idea that the more local governments are corrupted, the less incentive they have to maintain a sound financial condition. The magnitude of the coefficient for integrity is largest in model 4, while smallest in model 1.

Control variables are estimated to have positive and statistically significant coeffi- 
Table 5. Estimation Results

\begin{tabular}{|c|c|c|c|c|}
\hline & \multicolumn{4}{|c|}{ Dependent variable: Debt ratio compared to budget } \\
\hline & Model 1 & Model 2 & Model 3 & Model 4 \\
\hline Constant term & $\begin{array}{l}17.0320^{* * *} \\
(3.713)\end{array}$ & $\begin{array}{l}35.6843^{\star \star *} \\
(6.617)\end{array}$ & $\begin{array}{l}34.7477^{\star \star \star *} \\
(6.366)\end{array}$ & $\begin{array}{l}39.7487^{\star * *} \\
(5.684)\end{array}$ \\
\hline Integrity & $\begin{array}{l}-1.2512^{* * *} \\
(0.465)\end{array}$ & $\begin{array}{l}-3.5714^{* * *} \\
(0.790)\end{array}$ & $\begin{array}{l}-3.1530^{* * *} \\
(0.762)\end{array}$ & $\begin{array}{l}-4.8934^{\star \star \star} \\
(0.690)\end{array}$ \\
\hline Index & & $\begin{array}{l}7.9928^{* * *} \\
(0.909)\end{array}$ & $\begin{array}{l}10.0420^{\star \star *} \\
(0.917)\end{array}$ & \\
\hline Population & & $\begin{array}{l}\text { 1.07E-08 }{ }^{* * \star} \\
(1.92 \mathrm{E}-09)\end{array}$ & $\begin{array}{l}9.03 \mathrm{E}-07^{\text {***}} \\
(1.85 \mathrm{E}-07)\end{array}$ & $\begin{array}{l}\text { 1.38E-06** } \\
(1.74 \mathrm{E}-07)\end{array}$ \\
\hline Consolidated balance & & & $\begin{array}{l}0.4026^{\star \star *} \\
(0.054)\end{array}$ & $\begin{array}{l}0.3151^{\text {*** }} \\
(0.062)\end{array}$ \\
\hline Fiscal autonomy & & & & $\begin{array}{l}0.0918^{* * *} \\
(0.026)\end{array}$ \\
\hline 2011 & & $\begin{array}{l}-0.2715 \\
(0.703)\end{array}$ & $\begin{array}{l}-0.5560 \\
(0.677)\end{array}$ & \\
\hline 2012 & & $\begin{array}{l}-4.2683^{\text {** }} \\
(0.933)\end{array}$ & $\begin{array}{l}-4.3146^{\star \star \star} \\
(0.898)\end{array}$ & \\
\hline 2013 & & $\begin{array}{l}-5.2651^{* * *} \\
(0.964)\end{array}$ & $\begin{array}{l}-5.0532^{\star \star *} \\
(0.927)\end{array}$ & $\begin{array}{l}-1.1654^{\star *} \\
(0.504)\end{array}$ \\
\hline R-squared & 0.0071 & 0.2516 & 0.3086 & 0.3132 \\
\hline Adj R-squared & 0.0061 & 0.2449 & 0.3014 & 0.3063 \\
\hline
\end{tabular}

Note: Numbers in parentheses represent standard errors

${ }^{*},{ }^{* *},{ }^{* * *}$ : statistically significant at $10 \%, 5 \%$, and $1 \%$ respectively.

cients, Fiscal Power Index, Population, Consolidated Budget Balance and Fiscal Autonomy all alike. Year dummies are also statistically significant except for year 2011.

We can obtain the following claims with this results. The local governments who have high fiscal transparency would recognize their residents who control the local governments and they may actually have institutions which could control fiscal transparency such as revealing fiscal information to the public and participatory budgeting. And this may act as an incentive for the local government to reduce the debt. Moreover, the less corrupted local governments may not be captured by the lobbyist but are likely to focus more on the public's opinion. 


\section{CONCLUSION}

For a long history of studies, scholars have tried to pinpoint the exact association of corruption with economic effects. However, it is hardly found any study investigating the relationship between corruption and financial management at local government level.

This study empirically tested the argument that corruption undermines local government's incentives for good financial management and increase the debt level with unique Korean index; integrity score published by Anti-Corruption \& Civil Right Commission of Korea. According to OLS analysis, integrity has a negative and significant effect on the debt ratio in all models. In other words, the less corrupted local government operates sound finance. It might be argued that the study is meaningful in that it investigated the effects of corruption on financial management of local governments while presenting objective data which shows a reason for the bad financial situation in local governments, corruption.

The main limits of this paper, however, come from the data set. Time span is only from 2010 to 2013. For this reason, it might be hard to generalize the conclusion until a better data set is obtained.

\section{REFERENCES}

ADB. 2001. Improving public administration in a competitive world.

Aidt, T. S. 2003. Economic analysis of corruption: A survey. Economic Journal, 113: F632-F652.

Aidt, T. S., Duttab, J., \& Senac, Z. 2008. Governance regimes, corruption and growth: Theory and evidence. Journal of Comparative Economics, 36(1-2): 195-220.

Alexeev, M. \& Habodaszova, L. 2012. Fiscal decentralization, corruption, and the shadow economy. Public Finance and Management, 12(1): 74-99.

Arikan, G. G. 2004. Fiscal decentralization: A remedy for corruption? International Tax and Public Finance, 11: 175-195.

Arvate, P. R., Curi, A. Z., Rocha, F., \& Miessi Sanches, F. A. 2010. Corruption and the size of government: Causality tests for OECD and Latin American countries. Applied Economics Letters, 17(10-12): 1013-1017.

Assiotis, A., Sylwester, K. 2014. Do the effects of corruption upon growth differ between democracies and autocracies? Review of Development Economics, 18(3): 581-594.

Bardhan, P. 2002. Decentralization of governance and development. Journal of Economic 
Perspectives, 16: 185-206.

Beck, P. J. \& Maher, M. 1986. A comparison of bribery and bidding in thin markets. Economics Letters, 20: 1-5.

Bjedov, T., Madies, T., \& Schnyder, S. 2010. Corruption and decentralization: What economists have to say about it. Urban Public Economics Review, 13: 13-33.

De Mello, L. \& Matias B. 2001. Fiscal decentralization and governance: A crosscountry analysis. Working Paper 01-171. Washington, DC, IMF.

Depken, C. A. II \& Lafountain, C. L. 2006. Fiscal consequences of public corruption: Empirical evidence from state bond ratings. Public Choice, 126(1-2): 75-85.

Dincer, O. C., Ellis, C. J., \& Waddell, G. R. 2010. Corruption, decentralization and yardstick competition. Economics of Governance, 11(3): 269-294.

Dzhumashev, R. 2014. The two-way relationship between government spending and corruption and its effects on economic growth. Contemporary Economic Policy, 32(2): 403-419.

Fisman, R. \& Gatti, R. 2002. Decentralization and corruption: Evidence from U.S. federal transfer programs. Public Choice, 113(1-2): 25-35.

Goel, R. K. \& Nelson, M. A. 2011. Government fragmentation versus fiscal decentralization and corruption. Public Choice, 148(3-4): 471-490.

Goerke, L. 2008. Bureaucratic corruption and profit tax evasion images. Economics of Governance, 9(2): 177-196.

Huther, J. \& Anwar S. 1998. Applying a simple measure of good governance to the debate on fiscal decentralization. Working Paper 1894. Washington, DC, World Bank.

Huntington, S. 1968. Modernization and corruption. In Arnold J. Heidenheimer \& Michael Johnston (eds), Political Corruption: Concepts and Contexts.

Jain, A. K. 2001. Corruption: A review. Journal of Economic Surveys, 15: 71-121.

Knack, S. \& Keefer, P. 1995. Institutions and economic performance: Cross-country tests using alternative institutional indicators. Economics and Politics, 7(3): 207-228.

Kwon, G. H. 2004. The impacts of Korea's financial crisis on the changes in the spending patterns of local public expenditures. Korean Journal of Public Administration, 42(4): 211-237.

Lambsdorff, J. G. 2006. Causes and consequences of corruption: what do we know from a cross-section of countries? In S. Rose-Ackerman (ed.), International handbook on the economics of corruption (pp. 3-51). Cheltenham: Edward Elgar.

La Porta, R., Lopez-de-Silanes, F., Shleifer, A., \& Vishny, R. 1999. The quality of government. Journal of Law, Economics, and Organization, 15: 222-279.

Lecuna, A. 2012. Corruption and size decentralization. Journal of Applied Economics, 
15(1): 139-68.

Lee, J. S. 2007. Empirical analysis of local government financial capacity: Focusing on financial index analysis. The Korean Journal of Public Policy Studies, 21(2): 101-120.

Lien, Da-Hsiang D. 1986. A note on competitive bribery games. Economics Letters, 22: 337-341.

Meon, P. G \& Sekket, K. 2005. Corruption grease or sand the wheels of growth? Public Choice, 122(1-2): 69-97.

Michael, S. 2002. Corruption and public finance. Management Systems International, November, 2002.

Moschovis, G. 2010. Public spending allocation, fiscal performance and corruption. Economic Papers, 29(1): 64-79.

Oates, W. 1972. Federal fiscalism. New York, NY: Harcourt Brace and Javonovich.

Prud'homme, R. 1995. The dangers of decentralization. The World Bank Research Observer, 10: 201-226.

Rock, M. \& Bonnett, H. 2004. The comparative politics of corruption: Accounting for the East Asian paradox in empirical studies of corruption. Growth and Investment. World Development, 32(6): 999-1017.

Shleifer, A. \& Robert, V. 1993. Corruption. Quarterly Journal of Economics, 108: 599-617.

Svensson, J. 2005. Eight questions about corruption. Journal of Economic Perspectives, 19: $19-42$.

Tanzi, V. 1995. Fiscal federalism and decentralization: A review of some efficiency and macroeconomic aspects. Annual World Bank Conference on Development Economics. Washington, DC, World Bank, 1995.

Tanzi, V. 1998. Corruption around the world: Causes, consequences, scope, and cures. Working Paper 45-4. Washington, DC, IMF.

Ugur, M. 2014. Corruption's direct effects on per-capita income growth: A metaanalysis. Journal of Economic Surveys, 28(3): 472-490.

Wijewardena, W. A. 2015. Delay in fighting corruption: An impatient electorate shouldn't be taken lightly. Colombo Telegraph, February 16, 2015. 